\title{
A deleterious diptilomiopid mite (Acari: Eriophyoidea): host plant relationship
}

\author{
Carlos H. W. Flechtmann ${ }^{1 \neq \pm(-\infty}$, Elias S. Figueiredo ${ }^{2(1)}$
}

${ }^{1}$ Departamento de Entomologia e Acarologia, Escola Superior de Agricultura "Luiz de Queiroz", Universidade de São Paulo, Piracicaba, São Paulo, Brazil. 'Laboratório de Acarologia, Centro Avançado de Pesquisa em Proteção de Plantas, Instituto Biológico, Campinas, São Paulo, Brazil.

拝三“Corresponding author: chwflech@usp.br

Edited by: Peterson R. Demite

Received: March 29, 2020. Accepted: June 02, 2020. Published: July 08, 2020.

Abstract. A case where a diptilomiopid eriophyoid mite kills its host plant is reported. Rhynacus acerioides Flechtmann, 2014 is recorded for the first time in Brazil. A key to species of the genus is provided.

Keywords: Capsicum chinense, Diptilomiopidae, geographical distribution, Rhynacus, Solanaceae.

Rhynacus Keifer, 1951 is a small genus of Diptilomiopidae (Acari: Eriophyoidea), which currently has five species: $R$. abronius (Keifer, 1939), R. acerioides Flechtmann, 2014, R. arctostaphyli (Keifer, 1938), R. kraussii Keifer, 1962 and R. lippius Duarte, Chetverikov \& Navia, 2016. In Brazil, the only species recorded to date is $R$. lippius (Duarte et al. 2016).

Information of various authors on the nature and damage of the eriophyoid - host plant relationship were summarized by Royalti \& Perring (1996) and pointed out that "interestingly, leaf vagrants in the family Diptilomiopidae have mouth parts long enough to reach the mesophyll tissue of the leaves yet do not cause noticeable damage to their host plants".

In this study, $R$. acerioides is registered for the first time in Brazil and a deleterious case of this mite on Capsicum chinense Jacquin (Solanaceae) is reported.

Diptilomiopid mites were collected from leaves of $C$. chinense (pimenta cumari do Pará, in Portuguese) plants in a domiciliar herb garden, located in Piracicaba $\left(22^{\circ} 42^{\prime} 30^{\prime \prime} S, 47^{\circ} 38^{\prime} 00^{\prime \prime} \mathrm{W}\right)$, São Paulo, Brazil. The infested leaves were examined under stereoscope at 20 and $40 \mathrm{X}$, mounted on microscopy slides with modified Berlese medium and identified under phase contrast microcopy. The voucher specimens are deposited at Acarology Collection of Departamento de Entomologia e Acarologia da Escola Superior de Agricultura "Luiz de Queiroz" (ESALQUSP), Piracicaba, São Paulo. Brazil.

The mites were identified as R. acerioides Flechtmann, 2014. This dipitlomiopid was described from leaves of a Solanaceae weed in tobacco campus in Jujuy, Argentina, vagrants on the lower side of leaves (Flechtmann et al. 2014). In this study the specimens were found mainly on the lower side of leaves, but some specimens were collected on the upper side.

A few pot pepper grown plants thrived well until flowering. Then an infestation by $R$. acerioides occurred, certainly carried by wind from a nearby source. Its population increased rapidly and when reaching a density of ca. 100 specimens per square centimeter, all leaves rapidly dried and dropped. The skeletons of the plants were pruned; the new sprouts were immediately attacked by the mite, and the entire plants died. In the description of $R$. acerioides no visible symptoms being observed (Flechtmann et al. 2014).

With the registration of this study, $R$. acerioides is reported on two species of Solanaceae: $C$. chinense and $S$. aloysiifolium. In the description of $R$. acerioides, the plant host mentioned is $S$. lorentzii Bitter (Solanaceae), now considered junior synonym of $S$. aloysiifolium. The other species of Rhynacus are reported in plants of other families: R. abronius on Rubus vitrifolius (Rosaceae) (Keifer 1939), $R$. arctostaphyli on Arctostaphylos sp. (Ericaceae) (Keifer 1938), R. kraussii on Lantana camara (Verbenaceae) (Keifer 1962) and R. lippius on Lippia alba (Verbenaceae) (Duarte et al. 2016). The geographical distribution of $R$. acerioides expands, now being reported in northern Argentina and southeastern Brazil (Fig. 1). The other species of the genus have been reported in Brazil, Colombia and USA (Keifer 1938, 1939, 1962; Duarte et al. 2016). Fiaboe et al. (2007) reported an undentermined species of Rhynacus from tomato and four species of wild Solanaceae, namely Solanum palinacanthum Dunal from the state of Paraiba, $S$. paniculatum L. from Bahia, Paraiba and Sergipe, S. stipulaceum Roem \& Schult. from Bahia, S. stramoniifolium Jacq. from Espírito Santo and S. thomasiifolium Sendtn. from Espírito Santo, Brazil.

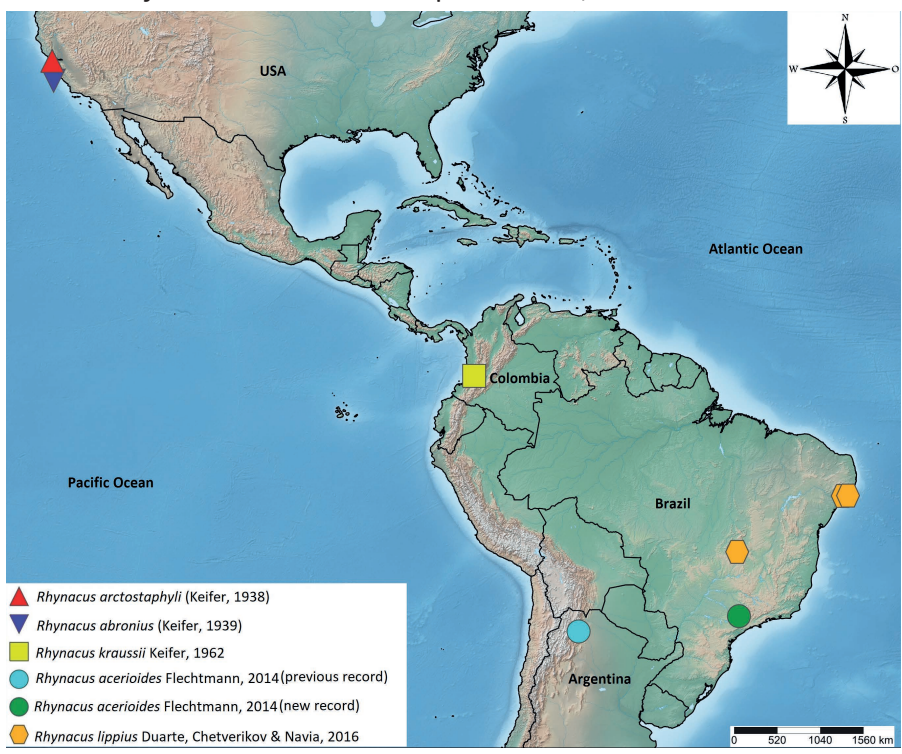

Figure 1. Geographical distribution of species of Rhynacus Keifer, 1951. 
Key to species of Rhynacus (females) (Updated of Flechtmann et al. 2014)

1. Prodorsal shield without scapular tubercles (but present in nymph); epigynum smooth R. acerioides Flechtmann, 2014

- Prodorsal shield with scapular tubercles; epigynum ornate or smooth 2

2. Epigynum smooth R. arctostaphyli (Keifer, 1938)

- Epigynum ornate (posterior half with dashes or longitudinal ribs and basally granulated) 3

3. Epigynum with strong longitudinal ribs R. kraussii Keifer, 1962

- Epigynum with short dashes 4

4. Dashes irregularly scattered R. abronius (Keifer, 1939)

- Dashes parallel, in a transverse row R. lippius Duarte, Chetverikov \& Navia, 2016

\section{Acknowledgements}

To CAPES (Brazilian Coordination for Improvement of Higher Education Personnel) by granting the Scholarship to second author.

\section{Authors' Contributions}

ESF grew the plants, detected the mite infestation and accompanied the development of the plants until their ultimate death. CHWF mounted and identified the mite, conducted the revision of literature and consulted with Dr. J.Amrine Jr., organizer of an Eriophyoidea data base. ESF \& CHWF wrote the note.

\section{References}

Duarte, M. E.; Chetverikov, P. E.; Silva, E. S.; Navia, D. (2016) Three new species of eriophyoid mites (Acariformes, Eriophyoidea) from Lippia alba (Verbenaceae) from Brazil and remarks on the thornlike spermathecal process. Systematic and Applied Acarology, 21(9): 1225-1249. doi: 10.11158/saa.21.9.7

Fiaboe, K. K. M.; Gondim Jr., M. G. C.; Moraes, G. J. de; Ogol, C. K. P. O.; Knapp, M. (2007) Surveys of natural enemies of the tomato red spider mites Tetranychus evansi (Acari: Tetranychidae) in northeastern and southeastern Brazil. Zootaxa, 1395: 33-58. doi: 10.11646/zootaxa.1395.1.2

Flechtmann, C. H. W.; Ballari, M. C.; Quintana de Quinteros, S. (2014) Eriophyoidea (Acari) on Solanaceous plants from Argentina, with description of a new species of Rhynacus (Diptilomiopidae) and a key to species. Systematic and Applied Acarology, 19(1): 73-78. doi: 10.11158/saa.19.1.6

Keifer, H. H. (1938) Eriophyid Studies II. Bulletin of the California Department of Agriculture, 27: 301-323.

Keifer, H. H. (1939) Eriophyid Studies VII. Bulletin of the California Department of Agriculture, 28: 484-505.

Keifer, H. H. (1962) Eriophyid Studies B-5. Bureau of Entomology, California Department of Agriculture, 20pp.

Royalti, R. N.; Perring, T. M. (1996) Nature of damage and its assessment. In: Lindquist, E. E.; Sabelis, M. W.; Bruin, J. (Eds.), Eriophyoid mites: their biology, natural enemies and control, pp. 493-512. Amsterdam: Elsevier. 